\title{
Thermal Analysis of Storage Cans Containing Special Nuclear Materials
}

by

J. W. Jerrell

Westinghouse Savannah River Company

Savannah River Site

Aiken, South Carolina 29808

P. S. Lam

DOE Contract No. DE-AC09-89SR18035

This paper was prepared in connection with work done under the above contract number with the U. S.

Department of Energy. By acceptance of this paper, the publisher and/or recipient acknowledges the U.S. Government's right to retain a nonexclusive, royalty-free license in and to any copyright covering this paper, along with the right to reproduce and to authorize others to reproduce all or part of the copyrighted paper. 


\section{DISCLAIMER}

This report was prepared as an account of work sponsored by an agency of the United States Government. Neither the United States Government nor any agency thereof, nor any of their employees, makes any warranty, express or implied, or assumes any legal liability or responsibility for the accuracy, completeness, or usefulness of any information, apparatus, product or process disclosed, or represents that its use would not infringe privately owned rights. Reference herein to any specific commercial product, process or service by trade name, trademark, manufacturer, or otherwise does not necessarily constitute or imply its endorsement, recommendation, or favoring by the United States Government or any agency thereof. The views and opinions of authors expressed herein do not necessarily state or reflect those of the United States Government or any agency thereof.

This report has been reproduced directly from the best available copy.

Available for sale to the public, in paper, from: U.S. Department of Commerce, National Technical Information Service, 5285 Port Royal Road, Springfield, VA 22161

phone: (800) 553-6847

fax: (703) 605-6900

email: orders@ntis.fedworld.gov

online ordering: http://www.ntis.gov/ordering.htm

Available electronically at http://www.doe.gov/bridge

Available for a processing fee to U.S. Department of Energy and its contractors, in paper, from: U.S. Department of Energy, Office of Scientific and Technical Information, P.O. Box 62, Oak Ridge, TN 37831-0062

phone: (865)576-8401

fax: (865)576-5728

email: reports@adonis.osti.gov 


\section{KEY WORDS: Thermal Analysis \\ Plutonium Oxides \\ Uranium Oxides \\ Storage \\ Vault \\ Plutonium Metal}

RETENTION PERIOD: LIFETIME

\section{Thermal Analysis of Storage Cans Containing Special Nuclear Materials (U)}

By

J. W. Jerrell

Poh-Sang Lam

ISSUED: October 15, 1994

SRTC SAVANNAh RIVER TECHNOLOGy CENTER, AIKEN, SC, 29808 Westinghouse Savannah River Company

Prepared for the U. S. Department of Energy under Contract DE-AC09-89SR 18035 


\section{DOCUMENT: - WSRC-TR-94-0418 \\ TITLE: Thermal Analysis of Storage Cans Containing Special Nuclear Materials (U)}

\section{APPROVALS}

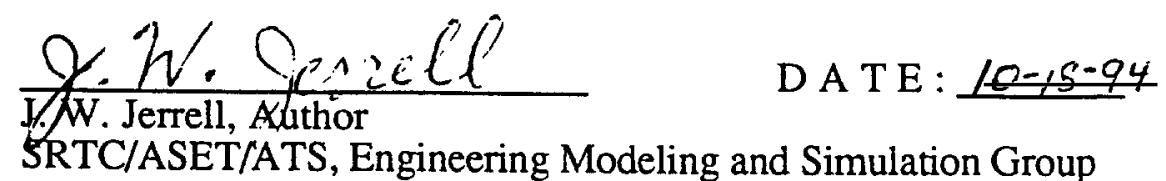

$\frac{P \cdot S \text { Lam }}{\text { P. Lam, Author }}$ D A T E : $10-18-94$

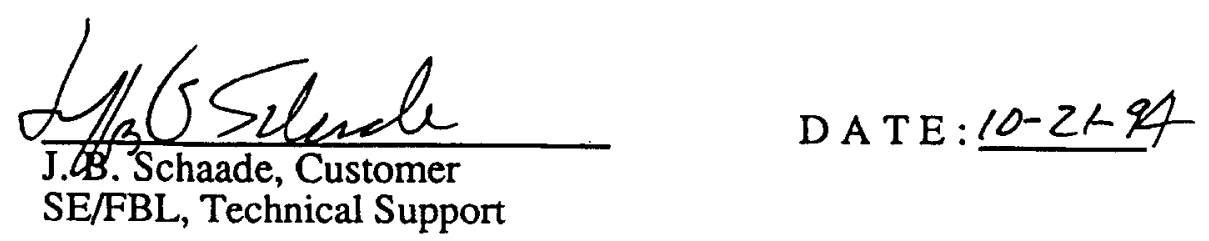

Gepeckrey D A TE: 12-4-94

J. Q Pelfrey, Group Manager

SRTC/ASET/ATS, Engineering Modeling and Simulation Group

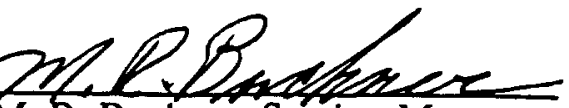

M. R. Buckner, Section Manager

D A T E : $12-6-94$

SRTC/ASET/ATS 


\begin{abstract}
Storage cans containing special nuclear materials in the F-area vaults may generate sufficient heat to affect the integrity of the plastic bags and cans containing the materials. As the stored material ages, heat and radiation degrade the plastic bags and rubber seals used in the cans and cause offgassing of the plastic. The offgassing of the plastic bags causes pressure accumulation within the cans and a loss of containment layer as the bags degrade. The temperature within the can is key to predicting storage life and developing proper material surveillance.
\end{abstract}

A series of thermal analyses have been completed for ten storage can configurations representing various cases of materials stored in F-area. The analyses determine the temperatures of the cans, the special nuclear material, and the air sealed within the cans. Analyses to aid in understanding the effect of oxide accumulation and metal aging on temperatures are also included.

The temperatures predicted quantify the effect of three observations: (1) temperatures increase when storing cans within larger cans; (2) inner air temperatures increase as a function of decreasing material density; and (3) the maximum localized can temperatures occur with a high density material. These results can serve as a basis for correlating oxidation rates and bag failure rates with material age and isotopic content. 


\subsection{Introduction}

Storage cans containing special nuclear materials (SNM) in the F-area vaults may generate sufficient heat to affect the integrity of the plastic bags and cans containing the materials. The materials, which exist in the form of metals, oxides, or combinations of the two, are typically packed in tin plated food cans using polyethylene or PVC bag-out bags. The can containing the SNM may be packed in one or two outer cans with a PVC or polyethylene bag between each can.

The food pack can configurations used for material storage typically rely on several different organic materials (within the can configuration) to ensure material containment. The plastic bag-out bags and the rubber seals in the food pack can lids are the two chief organics providing containment. As the stored material ages, the heat and radiation degrade the organics, causing the plastics to offgas and embrittle. Degradation of the plastics can cause pressure accumulation in the cans (from the offgassing of the plastic bags) or loss of a containment layer as the bags further degrade. To be able to predict the lifetime of the organic materials in the storage containers and help to develop proper material surveillance, the response of the organics to the storage environment is essential. A key aspect of this is the behavior of the plastics to the thermal flux provided by the contained material. Once the storage container temperatures are known, one aspect of the performance of the plastics during storage can be better predicted.

Several storage cans across the DOE complex have experienced pressurization and shown slight deformation of the cans and failure of the bags. One can from FB-Line was recently opened at SRTC and shown to have an internal pressure of approximately $15 \mathrm{psi}$ (see Appendix). The pressurization was shown to be from thermal breakdown and radiolysis of the PVC bag.

A series of thermal analyses has been completed for ten storage can configurations representing various cases of materials stored in F-area. The completed models are summarized in Table 1. The purpose of the analyses is to determine the temperatures of the SNM, cans, and air to aid in understanding the effect of oxide accumulation and metal aging on temperatures. These analyses can serve as a basis for correlating oxidation rates or bag failure rates with material age and isotopes.

\begin{tabular}{|c|c|c|c|c|}
\hline $\begin{array}{c}\text { Group- } \\
\text { Case }\end{array}$ & $\begin{array}{c}\text { Form and [Density] } \\
\left(\mathrm{g} / \mathrm{cm}^{3}\right)\end{array}$ & $\begin{array}{c}\text { Heat } \\
\text { Generation } \\
(\mathrm{W} / \mathrm{kg})\end{array}$ & $\begin{array}{c}\text { Mass of } \\
\text { SNM } \\
(\mathrm{kg})\end{array}$ & $\begin{array}{l}\text { Number } \\
\text { of Cans }\end{array}$ \\
\hline$\overline{\mathrm{Al}}$ & metal $\{19.4\}$ & 3.5 & 2.0 & $\overline{3}$ \\
\hline$\overline{\mathrm{A} 2}$ & metal $\{19.4\}$ & 4.0 & 2.0 & 3 \\
\hline $\mathrm{B} 3$ & oxide $\{1.5\}$ & 3.5 & 0.5 & $\overline{2}$ \\
\hline$\overline{\mathrm{B} 4}$ & oxide $\{1.5\}$ & 4.0 & 0.5 & 2 \\
\hline$\overline{\mathrm{B} 5}$ & oxide $\{11.0\}$ & 3.5 & 0.5 & $\frac{\pi}{2}$ \\
\hline B6 & oxide 11.0 & 4.0 & 0.5 & 2 \\
\hline$\overline{C 7}$ & metal & 3.0 & 2.25 & 2 \\
\hline $\mathrm{C} 8$ & metal $\{19.4\} \&$ oxide $(1.6)$ & 3.0 & 2.25 & 2 \\
\hline C9 & metal $(19.4\}$ \& oxide $\{3.0\}$ & 3.0 & 2.25 & 2 \\
\hline $\mathrm{C} 10$ & metal (19.4 \& oxide $[5.0]$ & 3.0 & 2.25 & 2 \\
\hline
\end{tabular}

Table 1: Summary of Thermal Models 


\subsection{Analysis Method}

The temperature distribution within the cans was calculated by developing $2 \mathrm{D}$ axisymmetric finite element models of the SNM, cans, and air contained between the cans. PATRAN3 (PDA Engineering, Costa Mesa, CA) was used for creating the geometry, finite element mesh, applying boundary conditions, and interpreting results. P/THERMAL, thermal analysis software developed by PDA

Engineering, performed the temperature calculations. Radiation view factors have been computed with P/VIEWFACTOR, a companion module to P/THERMAL.

All analyses were completed for steady-state conditions.

\subsection{Discussion}

\subsection{Dimensions}

Dimensions for the cans have been provided by the customer (see Appendix) and are shown in Table 2.

\begin{tabular}{|c|c|c|c|c|c|}
\hline Group & Case(s) & $\overline{\overline{S N M}}$ & Inner Can & Middle Can & Outer Can \\
\hline $\mathrm{A}$ & $1 \& 2$ & $3 \mathrm{H} \mathrm{x} 1.63 \mathrm{OD}$ & $3.5 \mathrm{H} \times 3.5 \mathrm{OD}$ & $\overline{5 \mathrm{H} \times 4 \mathrm{OD}}$ & $7 \mathrm{H} \times 4.25 \mathrm{OD}$ \\
\hline $\mathrm{B}$ & $3 \& 4$ & $3 \mathrm{H} \mathrm{x} 2.94 \mathrm{OD}$ & $3.5 \mathrm{H} \times 3.5 \mathrm{OD}$ & N/A & $4.6875 \mathrm{H} \times 3.875 \mathrm{OD}$ \\
\hline & $5 \& 6$ & $0.41 \mathrm{H} \times 2.94 \mathrm{O}$ & $3.5 \mathrm{H} \times 3.5 \mathrm{OD}$ & $\mathrm{N} / \mathrm{A}$ & $4.6875 \mathrm{H} \times 3.875 \mathrm{OD}$ \\
\hline C & 7 & $0.89 \mathrm{H} \times 3.75 \mathrm{OD}$ & $2.5 \mathrm{H} \times 3.75 \mathrm{OD}$ & N/A & $4.875 \mathrm{H} \times 4.25 \mathrm{OD}$ \\
\hline & 8 & $2.5 \mathrm{H} \times 3.75 \mathrm{OD}$ & $2.5 \mathrm{H} \times 3.75 \mathrm{OD}$ & N/A & $4.875 \mathrm{H} \times 4.25 \mathrm{OD}$ \\
\hline & 9 & $2.5 \mathrm{H} \times 3.75 \mathrm{OD}$ & $2.5 \mathrm{H} \times 3.75 \mathrm{OD}$ & $\mathrm{N} / \mathrm{A}$ & $4.875 \mathrm{H} \mathrm{x} 4.25 \mathrm{OD}$ \\
\hline & 10 & $2.5 \mathrm{H} \times 3.75 \mathrm{OD}$ & $2.5 \mathrm{H} \times 3.75 \mathrm{OD}$ & $N / A$ & $4.875 \mathrm{H} \times 4.25 \mathrm{OD}$ \\
\hline
\end{tabular}

Table 2: Model Dimensions (Inches) by Height $(\mathrm{H})$ and Outside Diameter (OD)

3.2 Modeling Assumptions

The shape of the SNM has a negligible effect on heat transfer. In all cases the SNM mass and density provide the correct volume as modeled. For the models in groups A and B there is some arbitrary space between the side of the SNM and innermost can. For the models in group $C$ the $S N M$ is modeled as a cylinder, having the radius of the inner can and a height chosen to approximate the volume of the hemispherical cap. These differences are not expected to contribute significantly to the overall heat transfer.

The upper can rims are not included in the models. The upper can rims only contact the air, and therefore do not act as significant conduction paths. Also, the 0.125 -inch height of the rims is sufficiently small relative to the cans so that the surface area provided by the upper rims does not significantly affect heat transfer.

In the FB-Line vaults the outermost can partially rests on a steel angle and is centered on the angle by a surrounding pipe ring. The pipe ring does not extend the full height of the outermost can. The pipe ring is not significant to the thermal analysis and was not included in the models. Although the cans partially rest on a steel angle, it is assumed that heat is convected and radiated from the outer can bottom to the environment without interference from the angle.

The outer can rim provides a conduction path between the cans and the steel angle upon which the cans rest. To simplify model development the lower can rim of 
the outer can was not included in the model. However, the effect of including the outer can rim on model temperatures was explored for the model of case $2 \mathrm{~A}$. Including the 0.125-inch high and 0.044-inch thick lower rim of the outermost can increased temperatures by less than eight degrees Fahrenheit. The largest temperature increase of $8^{\circ} \mathrm{F}$ occurred at the bottom outer edge of the outer can. The temperature increase at the center bottom of each of the three cans was approximately $2.5^{\circ} \mathrm{F}$. This exploratory analysis shows that the outermost can rim has a small effect on the overall temperature distribution and can be neglected.

The type of radionuclide is irrelevant since the analyses are băsed upon specified heat generation rates and masses supplied by the customer. The thermal conductivity of the metals and oxide forms are fairly independent of the radionuclide. Plutonium has been chosen as the typical contents.

\subsection{Heat Generation}

Heat is generated by radioactive decay of the SNM at the rates shown in Table 1. The heat generated is uniformly distributed throughout the oxide or metal for the models in groups A and B.

For cases 8 through 10 of group C, oxide forms on the top of the metal SNM analyzed in case 7 . The oxide completely fills the inner can space not occupied by the metal. The metal modeled in group $C$ contacts the entire bottom of the can and remains in contact with the bottom during formation of the oxide. The heat generated in the metal and oxide is proportional to the grams of radionuclide present in each component.

\subsection{Heat Transfer}

Heat is transferred from the SNM to the environment by conduction through the SNM, air, and steel as well as by radiation across the internal air gaps. The bags are not included in the models as they are thin and do not present a significant resistance to the heat transfer. The effect of natural convection on heat transfer within the cans is negligible. The surfaces of the cans are gray and diffuse with an emissivity of 0.2 [1]. The actual emissivity of the SNM is unknown but was assigned an emissivity of 0.5 as an estimate.

Heat loss to the environment occurs by both radiation and natural convection from the sides, top, and bottom of the outermost can. The ambient air temperature is $80^{\circ} \mathrm{F}$. The steel angle is modeled as an infinite heat sink with a constant temperature of $80^{\circ}$. F. The coefficients[2] for natural convection are shown in Table 3.

\begin{tabular}{|c|c|}
\hline Surface & Convection coefficient (Btu/hr- $\left.\mathrm{ft}^{2}-^{-} \mathrm{F}\right)$ \\
\hline Top & $0.22(\Delta \mathrm{T})^{1 / 3}$ \\
\hline Side & $0.19(\Delta T)^{1 / 3}$ \\
\hline Bottom & $0.16(\Delta T)^{1 / 4}$ \\
\hline
\end{tabular}

The outermost can radiates to an infinitely large enclosure having a constant temperature of $80^{\circ} \mathrm{F}$. No radiation exchange among the outermost cans or other components within the storage vault has been taken into account. 


\subsection{Thermal Properties}

The only thermal property required is the thermal conductivity, shown in Table 4.

The thermal conductivity of the metal and oxide was assumed to be constant over the temperatures calculated in this analyses; however, temperature dependent conductivity data for the air and carbon steel were readily available and used in the analyses. The conductivity for the air and steel is shown at only one temperature for brevity. Thermal conductivity of the oxide is not extensive and has been interpolated or extrapolated from the available literature.

\begin{tabular}{|c|c|}
\hline Material & Thermal Conductivity (Btu/hr-ft- $\left.{ }^{\circ} \mathrm{F}\right)$ \\
\hline$\overline{\text { Air [3] }}$ & $0.0184 @ 212^{\circ} \mathrm{F}$ \\
\hline Carbon steel [3] & $41.1245 @ 77^{\circ} \mathrm{F}$ \\
\hline$\overline{\text { Oxide@ }} 1 . \overline{5 \mathrm{~g} / \mathrm{cm}^{3}[4]}$ & 0.0400 \\
\hline Oxide@1.6 g/ $\mathrm{cm}^{3}[4]$ & 0.0476 \\
\hline Oxide@ $3.0 \mathrm{~g} / \mathrm{cm}^{3}[4]$ & 0.2261 \\
\hline Oxide@ @ $5.0 \mathrm{~g} / \mathrm{cm}^{3}[4]$ & 0.8946 \\
\hline Oxide@11.0 g/ $/ \mathrm{cm}^{3}[4]$ & 2.9000 \\
\hline Plutonium metal [3] & 4.8 \\
\hline
\end{tabular}

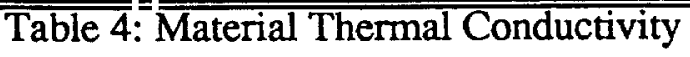

\subsection{Results}

Temperatures predicted by the finite element models are summarized in degrees Fahrenheit in Table 5 and in Figures 1 through 10. Maximum temperatures are shown to identify cases where the continuous service temperature of the plastic bag may be exceeded. The average air temperature of the inner and outer cans is reported for use in calculating internal air pressure.

The average air temperature is computed by averaging the nodal temperatures for each element and then summing the element temperatures as a volumetrically weighted average. Because air is entrained within the oxide powder, all elements representing oxide as well as air are included in computing the average air temperature. For the metal analyzed in cases 1,2, and 7 through 10, the metal is solid and not included in the elements contributing to the average air temperature. The average air temperature calculated for the outer can includes the internal can air and powder temperatures.

Figures 1 through 10 show temperatures at key points for each of the ten cases analyzed. The points were selected at the boundary extremes for the SNM and each can. There is an approximate linear variation between temperatures at the key points along the boundaries, such as along the sides and tops of the cans. Figures 1 through 10 are not drawn to scale. Temperatures on the figures are reported in degrees Fahrenheit. 


\begin{tabular}{|c|c|c|c|c|c|c|}
\hline $\begin{array}{l}\text { Group- } \\
\text { Case }\end{array}$ & $\begin{array}{c}\text { Avg Air } \\
\text { Temperature } \\
\text { of Inner Can } \\
\end{array}$ & $\begin{array}{l}\text { Average Air } \\
\text { Temperature } \\
\text { of Outer Can }\end{array}$ & $\begin{array}{c}\text { SNM } \\
\text { Maximum } \\
\text { Temperature }\end{array}$ & $\begin{array}{c}\text { Inner Can } \\
\text { Maximum } \\
\text { Temperature } \\
\end{array}$ & $\begin{array}{l}\text { Middle Can } \\
\text { Maximum } \\
\text { Temperature } \\
\end{array}$ & $\begin{array}{c}\text { Outer Can } \\
\text { Maximum } \\
\text { Temperature } \\
\end{array}$ \\
\hline$\overline{A-1}$ & 239 & 153 & 387 & 373 & 263 & 193 \\
\hline$A-2$ & 259 & 162 & 424 & 409 & 287 & 208 \\
\hline $\bar{B}-3$ & 125 & $1 \overline{12}$ & 160 & $1 \overline{12}$ & N/A & 96 \\
\hline B-4 & 131 & 117 & 171 & 116 & N/A & 98 \\
\hline$\overline{B-5}$ & 98 & $9 \overline{4}$ & $1 \overline{22}$ & $1 \overline{22}$ & N/A & 105 \\
\hline B-6 & 100 & 95 & 128 & 128 & $\mathrm{~N} / \mathrm{A}$ & 108 \\
\hline C-7 & 146 & 120 & $\overline{63}$ & $\overline{163}$ & $\mathrm{~N} / \mathrm{A}$ & 145 \\
\hline C-8 & 152 & 125 & 166 & 159 & $\mathrm{~N} / \mathrm{A}$ & $1 \overline{42}$ \\
\hline C-9 & $i \overline{51}$ & $1 \overline{28}$ & $1 \overline{59}$ & $\overline{154}$ & $\mathrm{~N} / \mathrm{A}$ & $i \overline{37}$ \\
\hline $\mathrm{C}-10$ & 152 & $1 \overline{29}$ & $1 \overline{56}$ & $\overline{156}$ & $\mathrm{~N} / \mathrm{A}$ & 132 \\
\hline
\end{tabular}

Table 5: Summary of Model Temperatures $\left({ }^{\circ} \mathrm{F}\right)$

Due to varying geometry, heat generation rates, and oxide densities, comparison of temperatures among the groups cannot be made as easily as comparison of temperatures among cases within the groups. Additionally, the temperatures reported in Table 5 are maximum temperatures for the component listed, and may occur at different locations for different cases. Temperature locations can be found in Figures 1 through 10. However, several observations from the data in Table 5 are worth noting.

Case 1 in group $\mathrm{A}$ has a metal SNM generating 7 watts and a resulting inner can average air temperature of $239^{\circ} \mathrm{F}$. Case 7 in group C has a metal SNM generating 6.75 watts and a resulting inner can average air temperature of $146^{\circ} \mathrm{F}$. The primary difference between the two models is a third can for the group A models. The addition of the third can increases the thermal resistance to heat flow to the environment and increases SNM, can, and air temperatures.

Group B cases 3 and 4 model a powder with a density of $1.5 \mathrm{~g} / \mathrm{cm}^{3}$ and Cases 5 and 6 model a powder with a density of $11.0 \mathrm{~g} / \mathrm{cm}^{3}$. A comparison can be made between cases 3 and 5 and between cases 4 and 6 because the heat generation rates are equal. The inner can average air temperature in case 3 is $27^{\circ} \mathrm{F}$ greater than the average air temperature in case 5 , and $31^{\circ} \mathrm{F}$ greater in case 4 than in case 6. The lower density oxide powder causes an increased average air temperature because of the steeper temperature gradient within the powder. It can also be seen that the high density oxide powder causes the maximum local can temperatures because of a greater localized heat flux.

The analyses for group $\mathrm{C}$ were completed to quantify the effect of decreasing oxide density on temperatures. Case 7 includes only the metal SNM. Cases 8 through 10 model the metal SNM covered with oxide powder at varying densities. The average air temperature of the inner can increases approximately $6^{\circ} \mathrm{F}$ from the case with the metal SNM (case 7) to the remaining cases with both the metal and oxide SNM. As expected, temperatures increase within the SNM with decreasing oxide density from $156^{\circ} \mathrm{F}$ (case 10 ) to $166^{\circ} \mathrm{F}$ (case 8). 


\subsection{Quality Assurance}

This project has been completed as a Level 2 calculation under the E7 Procedure Manual. Supporting calculations are documented in laboratory notebook WSRCNB-93-180 on pages 69 through 71,75 through 77 , and 87 through 91 . 


\section{References}

1. Robert Siegel and John Howell. Thermal Radiative Heat Transfer, 2nd. ed., Appendix D, Hemisphere Publishing Corporation, New York, NY (1981).

2. T. B. Baumister, et. al. Mark's Standard Handbook for Mechanical Engineers., 8th edition, pg 4-68, McGraw-Hill Book Company, New York, NY (1978).

3. PITHERMAL 2.6 (material library). PDA Engineering, PATRAN Division, Costa Mesa, CA (March 1993).

4. J. E. Evans and G. A. Gates. Safety Analysis Report - Packages - 238Pu Oxide Shipping Cask. p 40, DPSPU 74-124-1, Savannah River Plant, Aiken, SC (1975). 
pg. 8 of 17

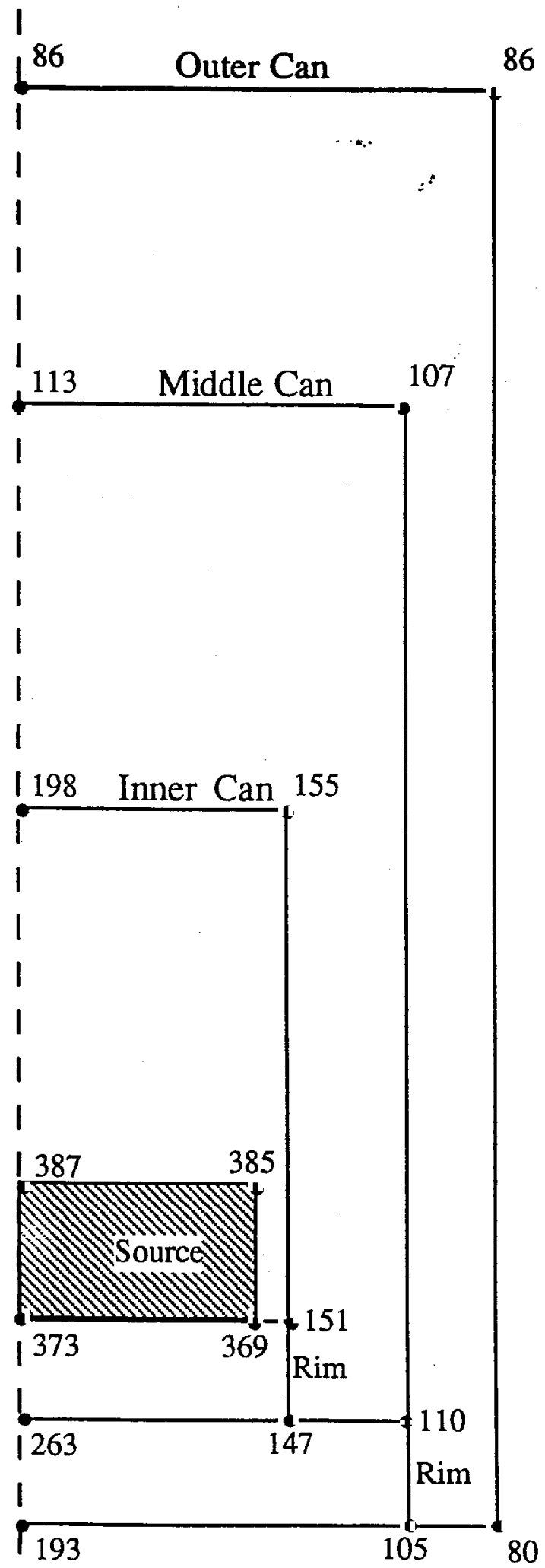

Figure 1: Metal at $19.4 \mathrm{~g} / \mathrm{cc}-3.5 \mathrm{~W} / \mathrm{kg}-2.0 \mathrm{~kg}$ ( Group A, Case 1 ) 


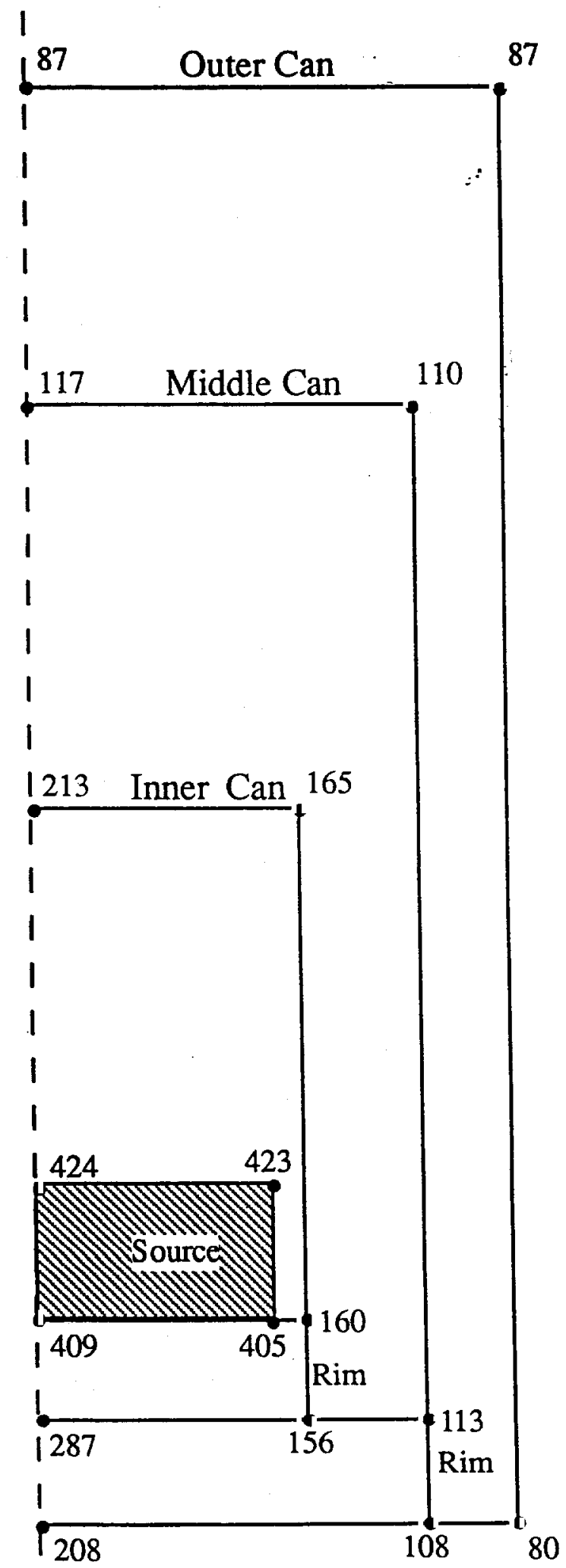

Figure 2: Metal at $19.4 \mathrm{~g} / \mathrm{cc}-4.0 \mathrm{~W} / \mathrm{kg}-2.0 \mathrm{~kg}$ ( Group A, Case 2) 
pg. 10 of 17

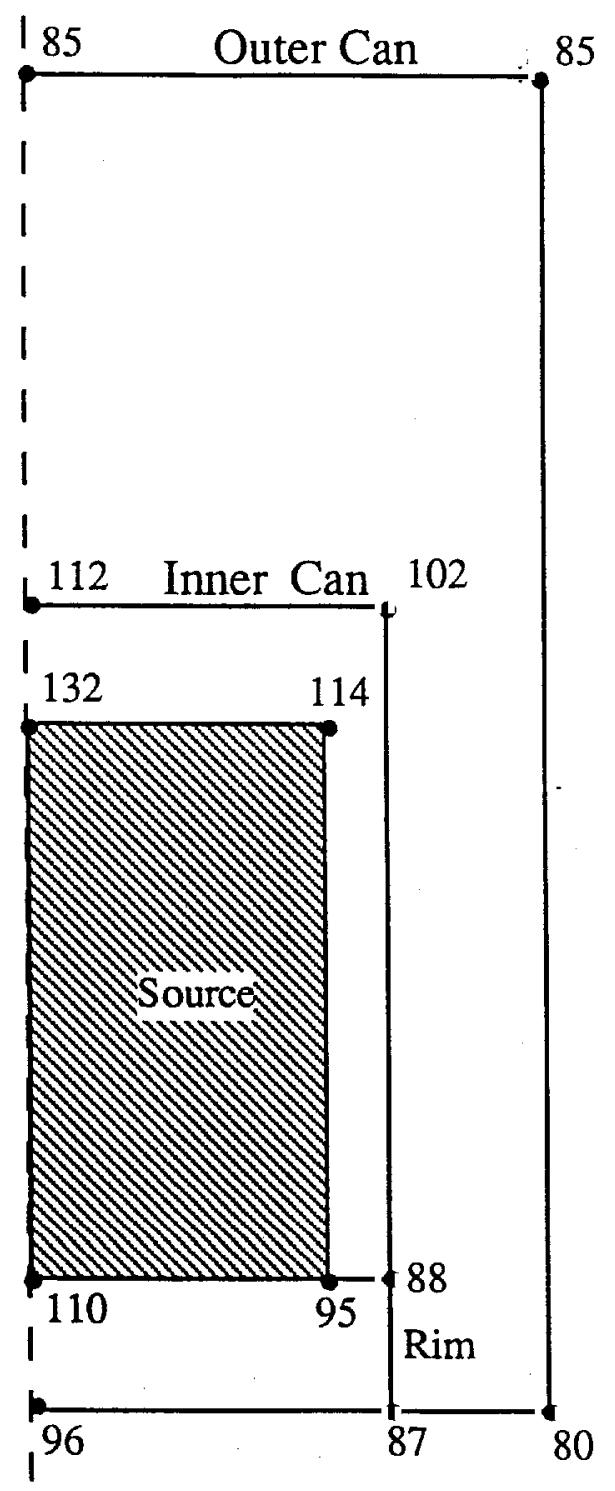

Figure 3: Oxide at $1.5 \mathrm{~g} / \mathrm{cc}-3.5 \mathrm{~W} / \mathrm{kg}-0.5 \mathrm{~kg}$ ( Group B, Case 3 ) 
pg. 11 of 17

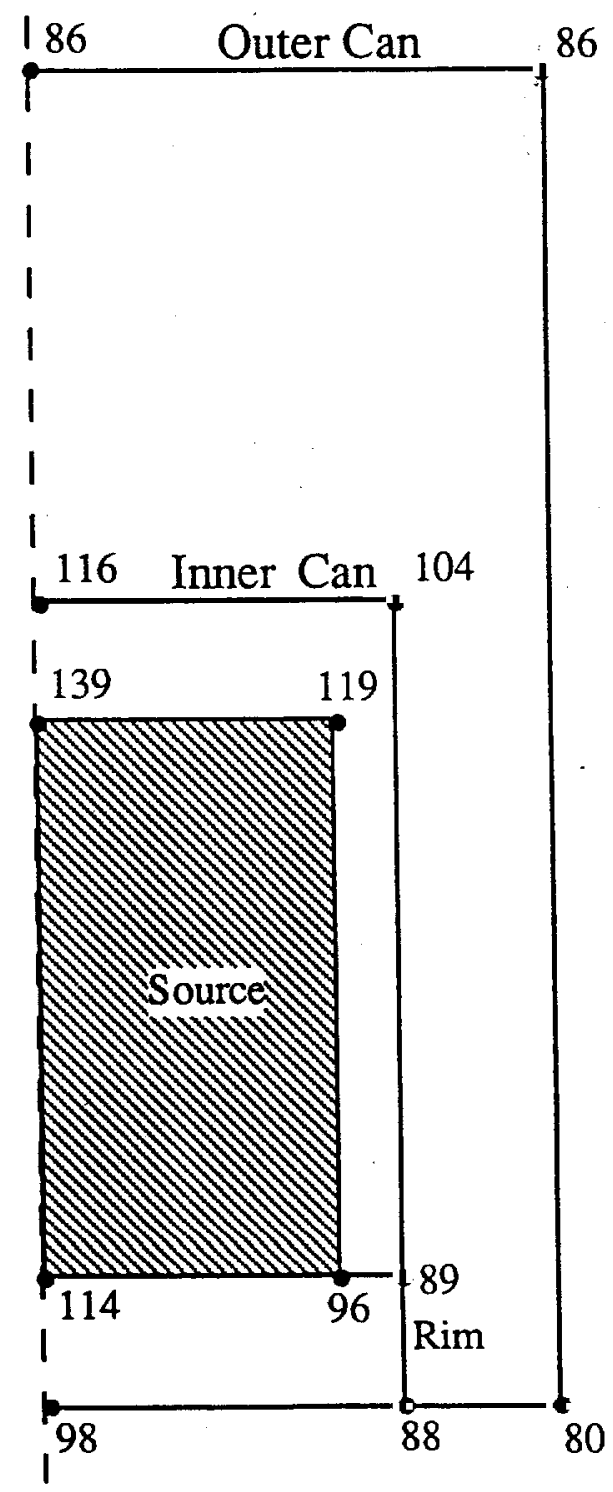

Figure 4: $\quad$ Oxide at $1.5 \mathrm{~g} / \mathrm{cc}-4.0 \mathrm{~W} / \mathrm{kg}-0.5 \mathrm{~kg}$ ( Group B, Case 4 ) 
pg. 12 of 17

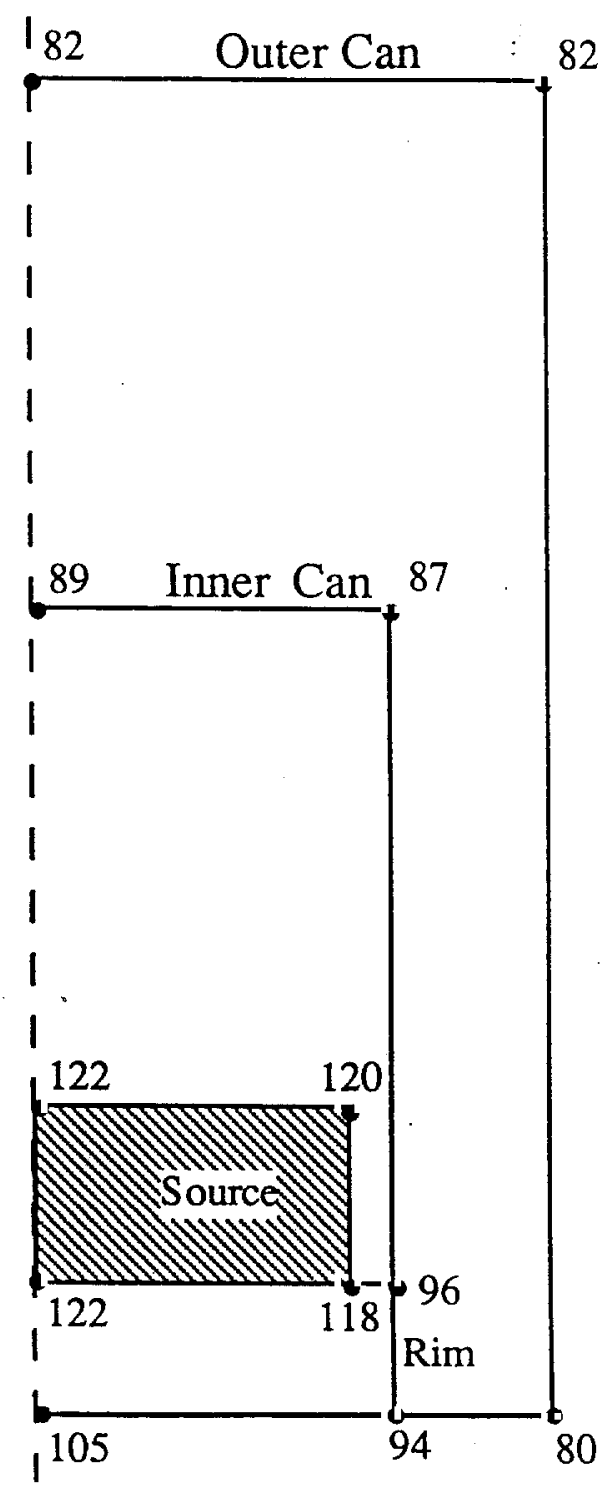

Figure 5: Oxide at $11.0 \mathrm{~g} / \mathrm{cc}-3.5 \mathrm{~W} / \mathrm{kg}-0.5 \mathrm{~kg}$ ( Group B, Case 5 ) 
pg. 13 of 17

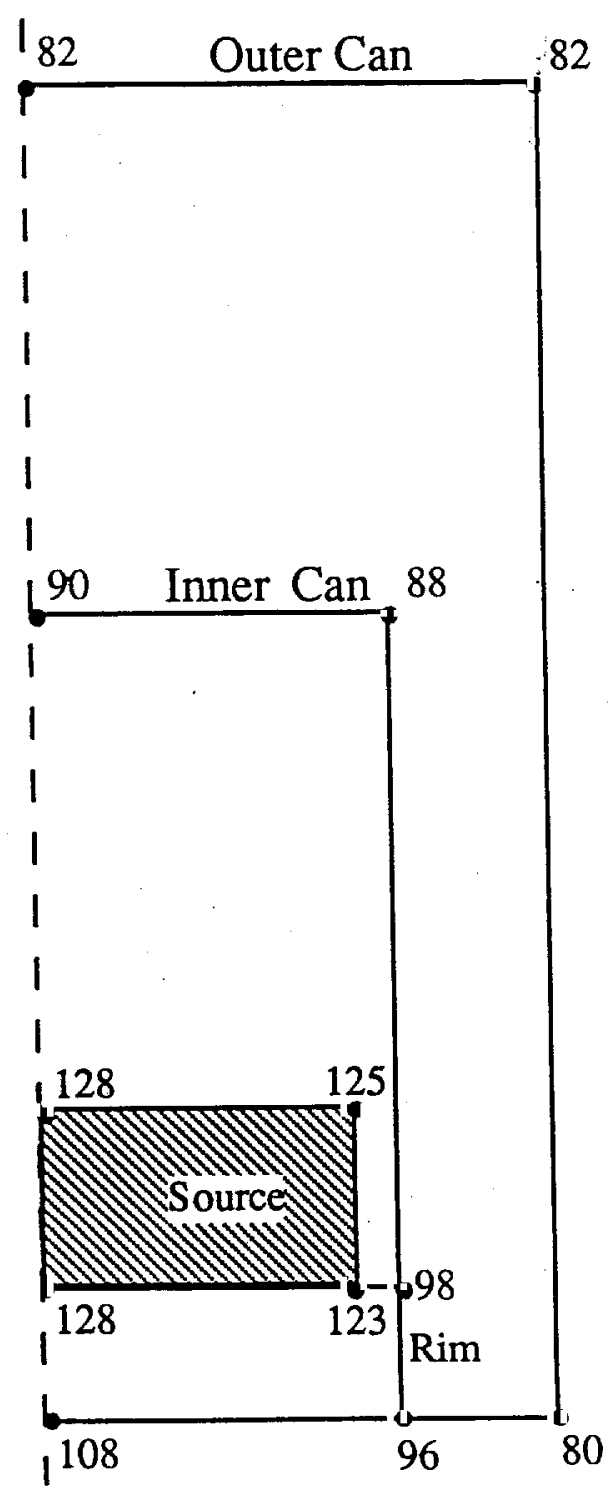

Figure 6: Oxide at $11.0 \mathrm{~g} / \mathrm{cc}-4.0 \mathrm{~W} / \mathrm{kg}-0.5 \mathrm{~kg}$ ( Group B, Case 6 ) 
pg. 14 of 17

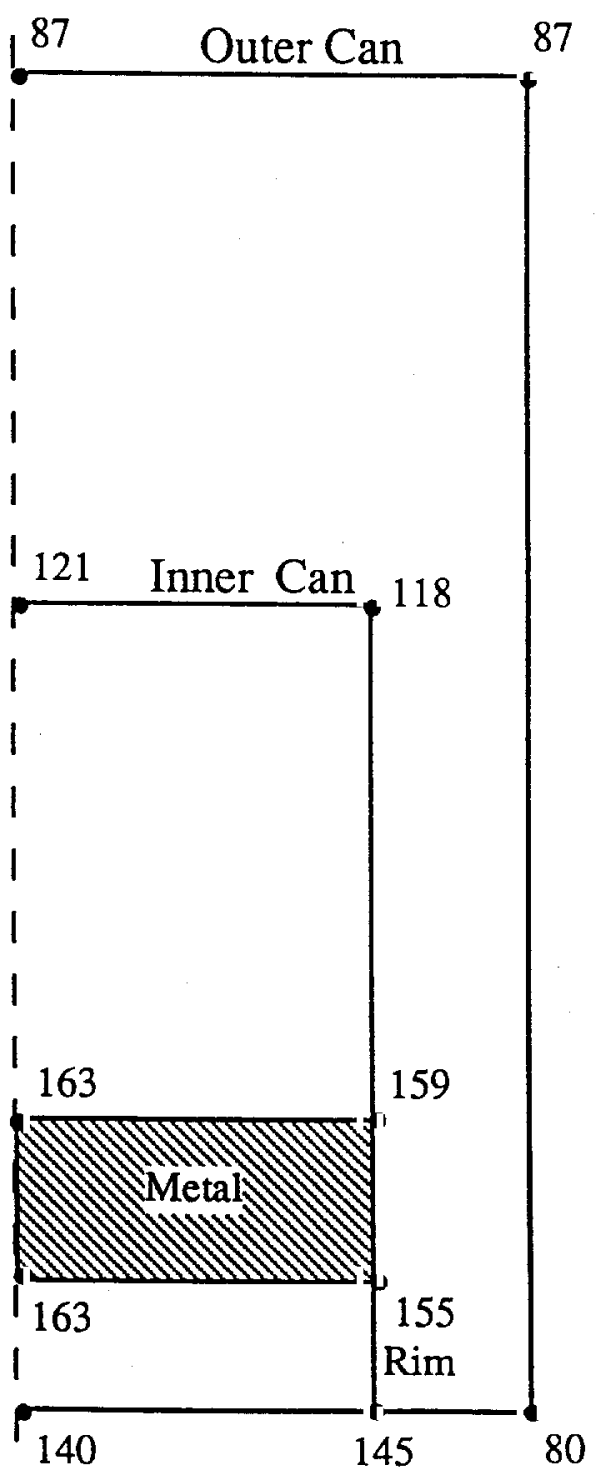

Figure 7: Metal - 3.0 W/kg - $2.25 \mathrm{~kg}$

(Group C - Case 7) 
pg. 15 of 17

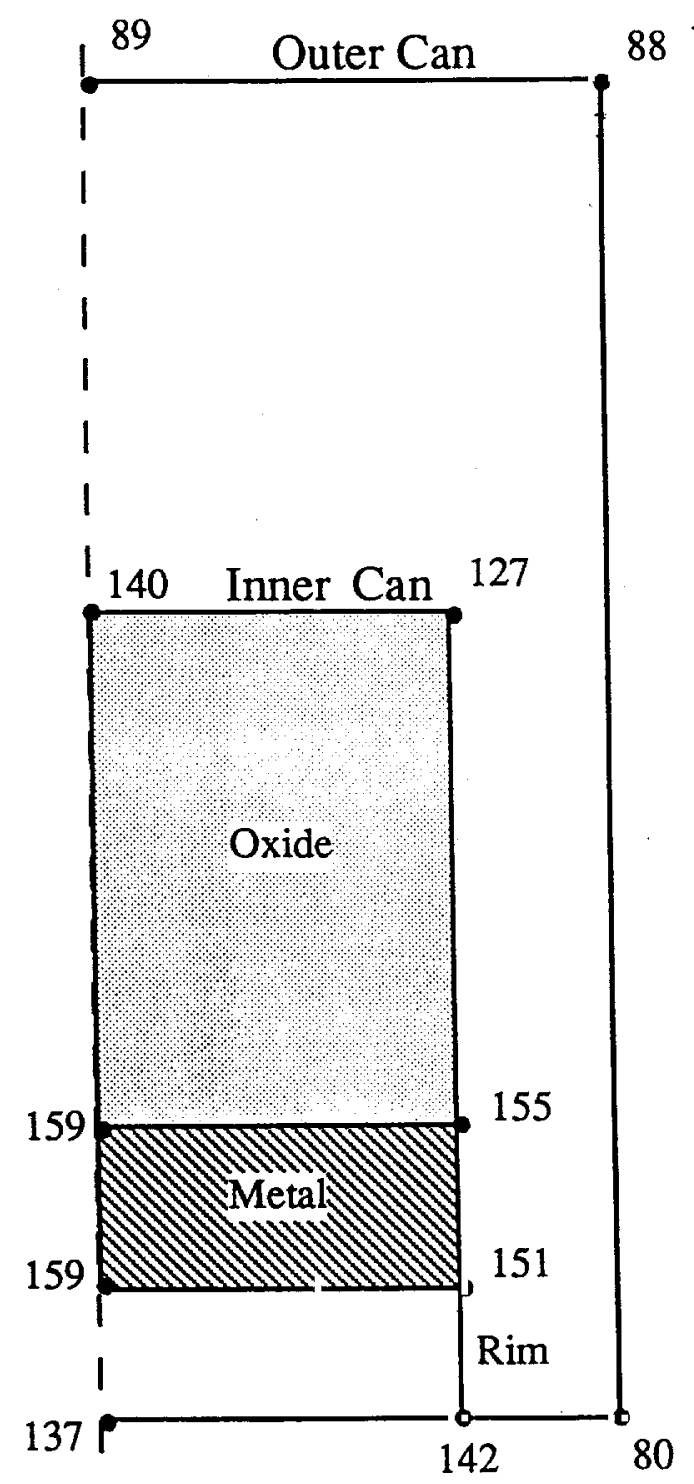

Figure 8: Metal \& Oxide at $1.6 \mathrm{~g} / \mathrm{cc}-3.0 \mathrm{~W} / \mathrm{kg}-2.25 \mathrm{~kg}$ (Group C - Case 8) 
pg. 16 of 17

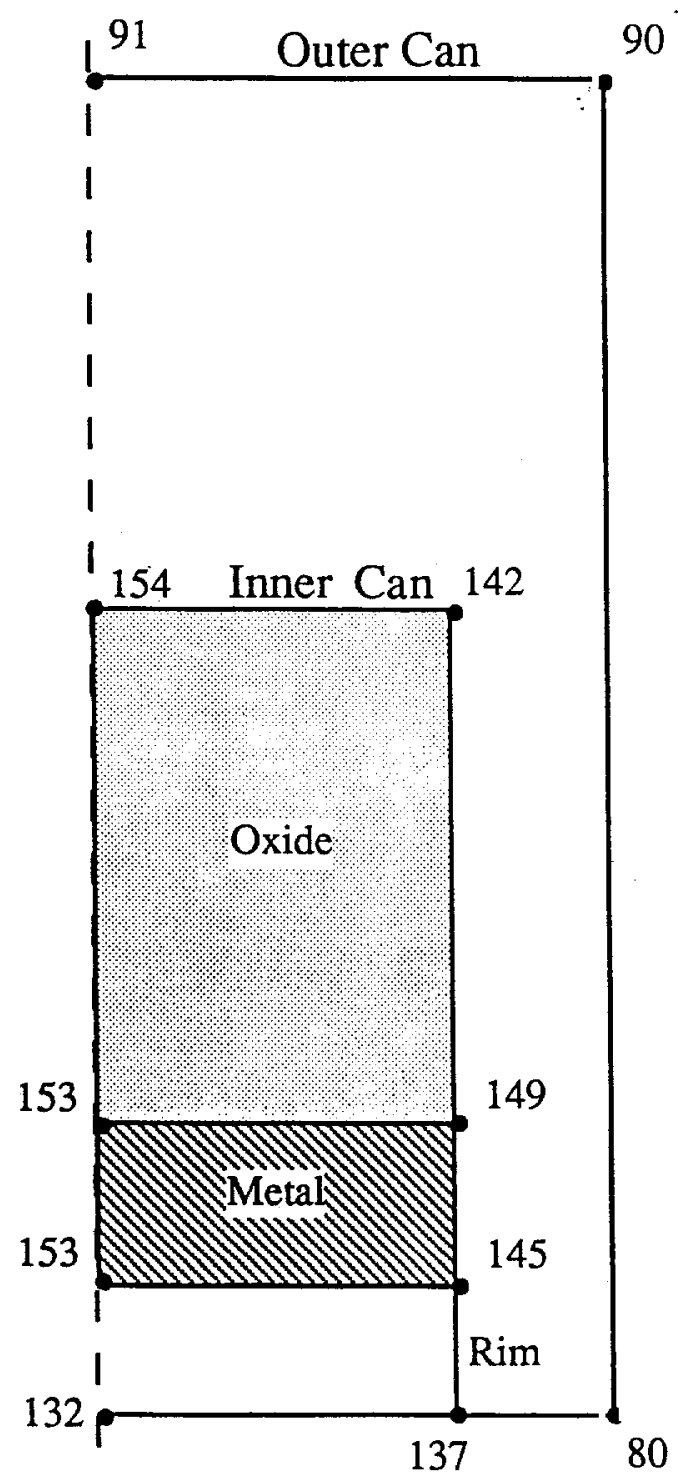

Figure 9: Metal \& Oxide at $3.0 \mathrm{~g} / \mathrm{cc}-3.0 \mathrm{~W} / \mathrm{kg}-2.25 \mathrm{~kg}$ (Group C - Case 9) 
pg. 17 of 17

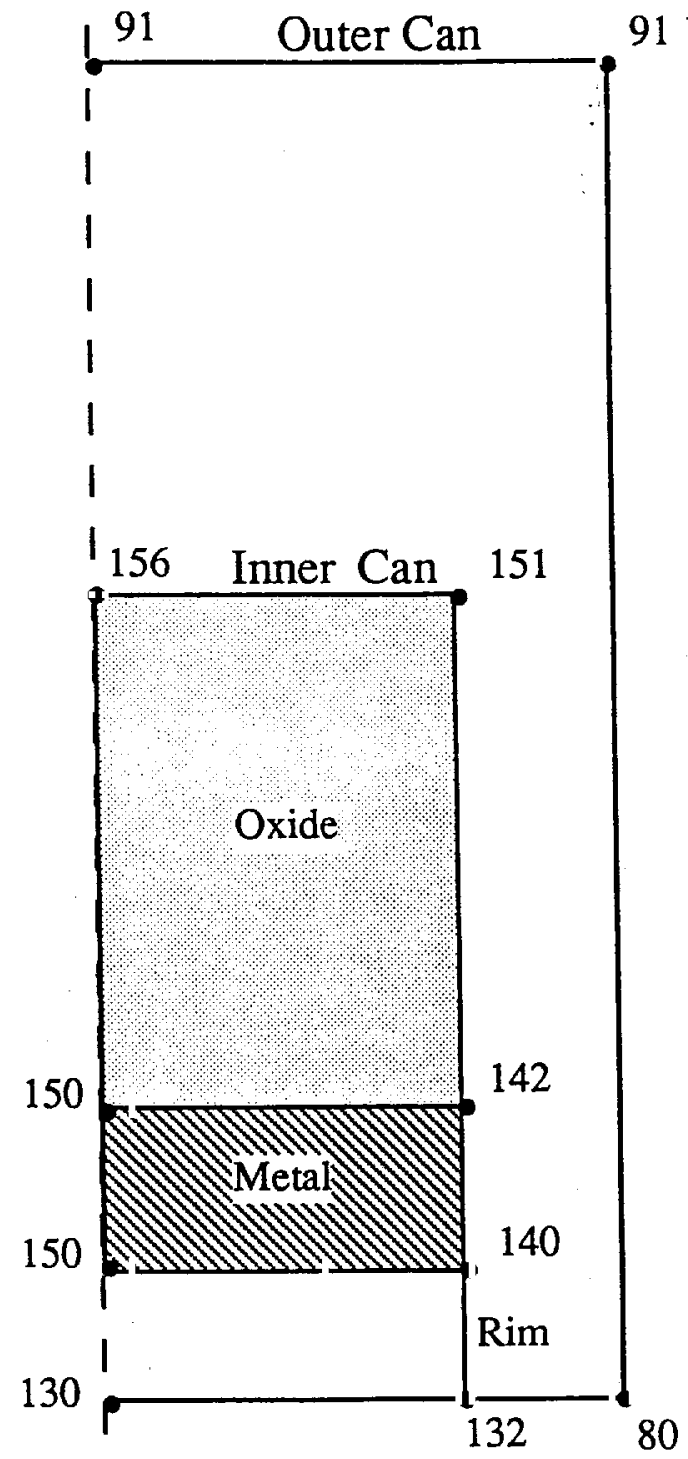

Figure 10: Metal \& Oxide at $5.0 \mathrm{~g} / \mathrm{cc}-3.0 \mathrm{~W} / \mathrm{kg}-2.25 \mathrm{~kg}$ (Group C - Case 10) 
APPENDIX 
INTER-OFEICE MENORANDUM

Savannah River Site

\section{3-Jun-1994 06:57am EDT}

To: Jeffrey $*$. Jerrell 5-1727

( JERRELI-JW-T8593)

From: JEFEERY B. SCHAADE

( SCEAADE-JB-T9304)

Dept: SE/FBI

TeI : 952-4758 Beeper 3393

\section{Can Temperature Modelling of Oxide}

First I would like to thank you for your assistance with the new can models with the rims and vault rack. This data falls more in line with the Banford data. Now that I see what a difference the rims make I was wondering about going back and re-doing the oxide temperature calculations.: Basicaliy, I would like to re-run the oxide models with rims on the cans and including the vault rack. The following better explains my request and details the pertinent information.

1) Please model 4 different scenarios.

a) 500 grams of 4 watts/Kg PuO2 e $11 \mathrm{~g} / \mathrm{cc}$

b) 500 grams of 4 watts $/ \mathrm{Kg} \mathrm{Pu}) 2 \mathrm{e} 1.5 \mathrm{~g} / \mathrm{cc}$

c) 500 grams of 3.5 watts $/ \mathrm{Kg} \mathrm{PuO2} \mathrm{e} 11 \mathrm{~g} / \mathrm{cc}$

d) 500 grams of 3.5 watts $/ \mathrm{kg}$ PuO2 e $1.5 \mathrm{~g} / \mathrm{cc}$

2) The packaging situation is can-bag-can where the cans are typical tin plated food pack cans. The inner can is $3.5^{\prime \prime}$ oD $x 3.5^{\prime \prime}$, the outer can is 3 $7 / 8 "$ OD and $411 / 16^{\prime \prime} \mathrm{B}$, and the bag is $20 \mathrm{mil}$ PVC.

3) I would like each can to be modelled with the can rims. I think before we discussed that these were about 1/8" deep and about 4-5 times as thick as the can wall. The can height specified above includes the rims and is an overall outer dimension. Hence, taking the rims into account, the actual usable can height would be the height dimension from above minus 2 (1/8) for the rims above and below the can.

4) I would appreciate color plots if possible.

Please call or beep me (e 3393) if you have nay questions. I appreciate the help. Thanks again. 
INTYR-OEFICE MBNORANDUM

Savannah River Site

06-Jun-1994 07:09am EDT

To: Jeffrey $*$. Jerrell 5-1727

( JERREII-JH-T8593)

From: JEFEERY B. SCHAADE

( SCEAADE-JB-T9304)

Dept: SE/FBI

Tel : 952-4758 Beeper 3393

\section{More Beat Transfer Analysis}

I really appreciate your help in modelling the Pu storage items; this is giving us a lot of meaningful information. I need to amend a pu metal packaging heat transfer model you did for us a while back. If you remember, this was with the 3.5 and 4 watts/kg metal. The change is to lower the mass:to $2000 \mathrm{~g}$ instead of $2500 \mathrm{~g}$, keeping everything else the same.

The following attributes remain the same from the previous model (aside from the mass).

1) $2000 \mathrm{~g}$ alpha $\mathrm{Pu}$ metal in an inner storage can roughly 3.5" $\mathrm{B}$ by 3.5 " OD. This is a typical tin-plated steel food-pack can. The ingot is a right circular cylinder shape piece of metal.

2) This inner can is double bagged in polyethylene. Each layer about $4 \mathrm{mils}$.

3) The double bagged inner can is then placed into another food-pack can about 4 " OD by 5" tall.

4) This item is then placed into a third food-pack can roughly 4.25" OD by 7" tall.

5) I would like to know the same temperature distributions as before along with the average air temeprature in the cans. Also, would it make much difference in the steady-state temperature if the can was resting on basically an infinite heat sink steel angle? This would better represent vault storage. From our conversations, it sounds like this would not make much differnce because the area for heat transfer out the botton of the can is very little (since the can actually touches the steel angle only on the can rim). However, could you model this along with convection off the bottom as well? While the temperatures may not change much, this will ahve been covered. Can you also_ send me color plots? 
INTER-OFEICE MEMORANDDM

Savannah River Site

28-JUI-1994 03:54pm EDT

To: Jeffrey $W$. Jerrell 5-1727

( JERRELL-JW-T8593)

CC: Poh-Sang Lam

CC: Rick Pelfrey, 5-8203

( IAAM-PS-L0200)

( PEIFREY-JR-07096)

From: JEFFERY B. SCHAADE

( SCHAADE-JB-T.9304)

Dept: SE/FBI

Tel : 952-4758. Beeper 3393

RE: Status

I do have some additional analyses I would like modelled. I would appreciate any help you could give me with these 3 scenarios.

1) A plutonium alpha phase metal button of 2250 grams at 3 . W/ kg packaged in 2 food pack cans. The button is first packaged in an inner food pack can (tuna can) about 2.5" tall and $3.75^{\prime \prime} \mathrm{OD}$. The food pack can wall thickness is as we discussed before, about 0.010". This inner can is then bagged in a $4 \mathrm{mil} P \mathrm{PE}$ bag and placed in a $4 / 8 "$ tali $\times 4.25^{\prime \prime}$ OD food pack can. This package then rests in the vault rack - very similar to the sketch I sent you. I would appreciate if you could include the rims in the food pack cans; these seem to make a big difference.

The shape of the button may be difficult to model. I would suggest that you initially try a hockey puck type ingot with a height about 0.89 ". The diameter should then come-out to about 3.75". In actuality, the buttons are curved on the button with a shape similar to a spherical cap. In this spherical cap, the button will still have a height of about $0.89 "$. but the spherical radius is 5 $1 / 8$ " inches. Anyway, I think trying the hockey puck is the right move for the first attempt.

2) Once the button model is completed, I would like to add oxide around the button to simulate metal oxidation with time. We recently repackaged a metal button which had significantly oxidized and the entire inner can was full of low density oxide. In this case, the PE bag around the inner can suffered severe heat damage. I think the oxide build-up around the button caused th equilibirum temperature to go up, thus significantly increasing the $P E$ bag degradation rate. For this model, fill the inner can with oxide keeping the button on the buttom of the can. Hence there will be no oxide on the can bottom. The oxide density should $1.6 \mathrm{~g} / \mathrm{cc}$. Please decrease the metal mass (and volume correspondingly) to make enough $\mathrm{Pu}$ oxide to fill the remaining void space.

3)

Try model number 2 with an oxide density of $3 \mathrm{~g} / \mathrm{cc}$ then $5 \mathrm{~g} / \mathrm{cc}$.

oltiamtely, I would like a graph showing how the button equilibrium temperature increases with oxide acumulation and oxide density. This can then be correlated to oxidation rate to help predict bag failure rates.

Some of this information may be a little sketchy, please give me a call if you have any questions at all or are unsure about exactly what $I$ want.

I really apreciate the help. Thanks. 